\title{
Synthesis, spectroscopic characterization, X-ray structure, and DFT calculations of $\left[\mathrm{Cu}(\mathrm{tppz})(\mathrm{SCN})_{2}\right]$
}

\author{
B. Machura $\cdot$ A. Świtlicka $\cdot$ J. Palion • \\ R. Kruszynski
}

Received: 16 February 2012/Accepted: 3 April 2012/Published online: 15 May 2012

(C) The Author(s) 2012. This article is published with open access at Springerlink.com

\begin{abstract}
This article presents a combined experimental and computational study of $\left[\mathrm{Cu}(\mathrm{tppz})(\mathrm{SCN})_{2}\right]$, where $t$ tpz stands for 2,3,5,6-tetra-(2-pyridyl)pyrazine. The compound has been studied by IR, UV-Vis spectroscopy, and single crystal X-ray analysis. The geometry around copper atom may be described as a distorted square pyramid. The equatorial plane is defined by three nitrogen atoms of tpp $z$ and one nitrogen atom of thiocyanate group. The apical site is occupied by nitrogen atom of the second $\mathrm{SCN}^{-}$ion. The electronic spectrum of $\left[\mathrm{Cu}(\mathrm{tppz})(\mathrm{SCN})_{2}\right]$ was analyzed, and bands were assigned through the DFT/TDDFT procedures.
\end{abstract}

Keywords Copper(II) $\cdot$ 2,3,5,6-Tetra-(2-pyridyl)

pyrazine $\cdot \mathrm{X}$-ray structure $\cdot$ DFT calculations

\section{Introduction}

The pseudohalide ions $\left(\mathrm{N}_{3}^{-}, \mathrm{NCS}^{-}, \mathrm{NCO}^{-}\right.$, and $\left.\mathrm{N}(\mathrm{NC})_{2}^{-}\right)$ are versatile ligands that can bind transition metal ions in a variety of ways. They can act as monodentate ligands and as bridging ligands leading to the formation of mononuclear and polynuclear species with different dimensionality and nuclearity. Among these, the azide- and thiocyanatecontaining metal complexes are considered to be the most

B. Machura $(\bowtie) \cdot$ A. Świtlicka $\cdot$ J. Palion

Department of Crystallography, Institute of Chemistry, University of Silesia, 9th Szkolna St., 40-006 Katowice, Poland e-mail: basia@ich.us.edu.pl

\section{R. Kruszynski}

Department of X-ray Crystallography and Crystal Chemistry, Institute of General and Ecological Chemistry, Technical University of Lodz, 116 Żeromski St., 90-924 Lodz, Poland e-mail: rafal.kruszynski@p.lodz.pl investigated systems because of their diverse structures and applications in magnetic materials [1-7]. It has been widely reported that the EO bridging mode generally mediates ferromagnetic coupling, while the EE does antiferromagnetic coupling. Furthermore, EE and EO bridging modes may simultaneously exist in the same species, leading to different topologies and materials with unprecedented, magnetic behavior [8-10]. The thiocyanate ions behave with similar versatility of the azide ones, but they seem to be less efficiently as transmitters of magnetic interaction [8-10]. However, in contrast to the vast chemistry of azido-bridged complexes, number of structurally and magnetically characterized thiocyanato-bridged is significantly smaller. To permit detailed magneto-structural correlations, further studies are needed for thiocyanato-bridged compounds.

Azide- and thiocyanate ions are frequently used in combination with polydentated organic ligands for the preparation of coordination compounds of various dimensionalities [3, 11-15]. 2,3,5,6-Tetra-(2-pyridyl)pyrazine (tppz), originally synthesized by Goodwin and Lions in 1959 [16], belongs to such ligands. It has six potential donor sites and is able to act as a bidentate, tridentate, bisbidentate, tris-bidentate, and bis-tridentate, forming both mono- and polynuclear complexes [17-20]. Previous studies focused on the complex formation between tppz and pseudohalide ligands, and first-row transition metal ions showed that the nuclearity of the product strongly depends on the central ion, choice of anions, and the reaction conditions. It has been also established that tppz exhibits a remarkable efficiency to mediate magnetic interactions between paramagnetic centers separated by more than $6.4 \AA$. The largest antiferromagnetic interaction between copper(II) ions has been found in the dinuclear complexes $\left[\mathrm{Cu}_{2}(\mathrm{tppz})\left(\mathrm{H}_{2} \mathrm{O}\right)_{4}\right]\left(\mathrm{ClO}_{4}\right)_{4} \cdot 2 \mathrm{H}_{2} \mathrm{O} \quad\left(J=-61.1 \mathrm{~cm}^{-1}\right)$ and 
$\left[\mathrm{Ni}_{2}(\mathrm{tppz})\left(\mathrm{H}_{2} \mathrm{O}\right)_{6}\right]\left(\mathrm{NO}_{3}\right)_{4} \cdot 2.5 \mathrm{H}_{2} \mathrm{O} \quad\left(J=-76 \mathrm{~cm}^{-1}\right) \quad[21$, 22]. Interestingly, the ability of tppz to mediate magnetic interactions between paramagnetic centers is much stronger than the related pyrazine molecule in its metal complexes where negligible or weak antiferromagnetic interactions were observed $(J$ values ranging from -7.4 to $0 \mathrm{~cm}^{-1}$ ) [20].

So far, several copper(II) complexes incorporating halide and pseudohalide ions and tppz ligand have been obtained and characterized. Among them are mononuclear $\left[\mathrm{Cu}(\mathrm{tppz}) \mathrm{Cl}_{2}\right],\left[\mathrm{Cu}(\mathrm{tppz})\left(\mathrm{N}_{3}\right)_{2}\right] \cdot 0.33 \mathrm{H}_{2} \mathrm{O},[\mathrm{Cu}(\mathrm{tppz})$ $\left.(\mathrm{NCO})_{2}\right] \cdot 0.4 \mathrm{H}_{2} \mathrm{O}$, dinuclear $\left[\{\mathrm{CuCl}\}_{2}(\mu\right.$-tppz) $]\left[\mathrm{PF}_{6}\right]_{2},\left[\mathrm{Cu}_{2}\right.$ (tppz) $\left.(\mathrm{dca})_{3}\left(\mathrm{H}_{2} \mathrm{O}\right)\right] \cdot d c a \cdot 3 \mathrm{H}_{2} \mathrm{O},\left[\mathrm{Cu}_{2}\left(\mu\right.\right.$-tppz) $\left.\mathrm{Cl}_{4}\right] \cdot 5 \mathrm{H}_{2} \mathrm{O},\left[\mathrm{Cu}_{2}\right.$ ( $\mu$-tppz) $\left.\mathrm{Br}_{4}\right]$ as well as one-dimensional $\left\{\left[\mathrm{Cu}_{2}(\mathrm{tppz})(\mathrm{tcm})_{4}\right]\right.$ $\left.3 / 2 \mathrm{H}_{2} \mathrm{O}\right\}_{n}$ and two-dimensional $\left\{\left[\mathrm{Cu}_{2}(\mathrm{tppz})\left(\mathrm{N}_{3}\right)_{2}\right]\left[\mathrm{Cu}_{2}\left(\mathrm{~N}_{3}\right)_{6}\right]\right\}_{n}$, $\left[\mathrm{Cu}_{5}(\mathrm{tppz})\left(\mathrm{N}_{3}\right)_{10}\right]_{n}$ structures [20, 23-25].

Surprisingly, studies on thiocyanate copper(II) complexes of tppz ligand have not been performed. Here, we present the synthesis, spectroscopic data, crystal, molecular and electronic structure of $\left[\mathrm{Cu}(\mathrm{tppz})(\mathrm{SCN})_{2}\right]$. To get a detailed insight into the electronic structure and spectroscopic properties of $\left[\mathrm{Cu}(\mathrm{tppz})(\mathrm{SCN})_{2}\right]$, we performed density functional theory (DFT) and time-dependent DFT (TD-DFT) calculations. Currently, DFT method is commonly used to examine transition metal complexes. It meets with the requirements of being accurate, easy to use and fast enough to allow the study of relatively large molecules of transition metal complexes [26].

\section{Experimental}

General procedure

The reagents used to the synthesis were commercially available and were used without further purification. IR spectrum was recorded on a Nicolet Magna 560 spectrophotometer in the spectral range $4000-400 \mathrm{~cm}^{-1}$ with the samples in the form of $\mathrm{KBr}$ pellets. Electronic spectrum was measured on a spectrophotometer Lab Alliance UV-VIS 8500 in the range $1000-180 \mathrm{~nm}$ in methanol solution.

\section{Preparation of $\left[\mathrm{Cu}(\mathrm{tppz})(\mathrm{SCN})_{2}\right]$}

$\mathrm{NH}_{4} \mathrm{SCN}$ (0.092 g, $\left.1.2 \mathrm{mmol}\right)$ was dissolved in water $(10 \mathrm{ml})$ and slowly added to the methanolic solution (15 ml) of $\mathrm{CuCl}_{2} \cdot 2 \mathrm{H}_{2} \mathrm{O}(0.1 \mathrm{~g} ; 0.59 \mathrm{mmol})$ and $2,3,5,6-$ tetra-(2-pyridyl)pyrazine $(0.59 \mathrm{mmol}, 0.23 \mathrm{~g})$ and stirred at room temperature for $6 \mathrm{~h}$. The resulting solution was kept for evaporation at room temperature, and after a few days green crystals of $\left[\mathrm{Cu}(\mathrm{tppz})(\mathrm{SCN})_{2}\right]$ were obtained, filtered off, and dried. Yield $70 \%$.
IR $\left(\mathrm{KBr} ; \mathrm{v} / \mathrm{cm}^{-1}\right)$ : 2069 (vs) and 2046(vs) $v\left(\mathrm{C}=\mathrm{N}_{\mathrm{SCN}}\right)$; 1650(w), 1600(m), 1568(w), and $1524(\mathrm{~s}) v\left(\mathrm{C}=\mathrm{N}_{\mathrm{tppz}}\right)$ and $v\left(\mathrm{C}=\mathrm{C}_{\mathrm{tppz}}\right)$.

X-ray diffraction studies

The X-ray intensity data of $\left[\mathrm{Cu}(\mathrm{tppz})(\mathrm{SCN})_{2}\right]$ were collected on an Gemini A Ultra Oxford Diffraction four-circle kappa geometry diffractometer with Atlas CCD detector graphite monochromated Mo $K_{\alpha}$ radiation $(\lambda=0.71073 \AA$ ) at $293(2)$ $K$. The unit cell determination and data integration were carried out using the CrysAlis package of Oxford Diffraction [19]. Intensity data were corrected for the Lorentz and polarization effects. The absorption correction was introduced by SCALE3 ABSPACK scaling algorithm [27]. The structure was solved by direct methods using SHELXS-97 and refined by full matrix least-squares on $\mathrm{F}_{\mathrm{o}}^{2}$ with SHELXL-97 with anisotropic displacement parameters for

Table 1 Crystal data and structure refinement for $\left[\mathrm{Cu}(\operatorname{tppz})(\mathrm{SCN})_{2}\right]$

\begin{tabular}{|c|c|}
\hline Empirical formula & $\mathrm{C}_{26} \mathrm{H}_{16} \mathrm{CuN}_{8} \mathrm{~S}_{2}$ \\
\hline Formula weight & 568.13 \\
\hline Temperature & 293.0(2) K \\
\hline Wavelength & $0.71073 \mathrm{~A}$ \\
\hline Crystal system & Orthorhombic \\
\hline Space group & Pna $2_{1}$ \\
\hline \multirow[t]{3}{*}{ Unit cell dimensions } & $a=16.9150(8) \AA$ \\
\hline & $b=19.7040(9) \AA$ \\
\hline & $c=7.2656(4) \AA$ \\
\hline Volume & $2421.6(2) \AA^{3}$ \\
\hline$Z$ & 4 \\
\hline Density (calculated) & $1.558 \mathrm{mg} / \mathrm{m}^{3}$ \\
\hline Absorption coefficient & $1.108 \mathrm{~mm}^{-1}$ \\
\hline$F(000)$ & 1156 \\
\hline Crystal size & $0.202 \times 0.070 \times 0.051 \mathrm{~mm}$ \\
\hline$\theta$ range for data collection & $3.33^{\circ}$ to $25.10^{\circ}$ \\
\hline \multirow[t]{3}{*}{ Index ranges } & $-18 \leq h \leq 20$ \\
\hline & $-23 \leq k \leq 19$ \\
\hline & $-8 \leq l \leq 7$ \\
\hline Reflections collected & 8275 \\
\hline Independent reflections & $3902[R($ int $)=0.0260]$ \\
\hline Completeness to $2 \theta=29.36^{\circ}$ & $99.7 \%$ \\
\hline Max. and min. transmission & 1.000 to 0.919 \\
\hline Data/restraints/parameters & $3902 / 1 / 335$ \\
\hline Goodness-of-fit on $F^{2}$ & 1.040 \\
\hline \multirow[t]{2}{*}{ Final $R$ indices $[I>2 \sigma(I)]$} & $R 1=0.0328$ \\
\hline & $\mathrm{w} R 2=0.0770$ \\
\hline \multirow[t]{2}{*}{$R$ indices (all data) } & $R 1=0.0396$ \\
\hline & $\mathrm{w} R 2=0.0802$ \\
\hline Absolute structure parameter & $0.00(8)$ \\
\hline Largest diff. peak and hole & 0.468 and $-0.221{\mathrm{e} \AA^{-3}}^{-3}$ \\
\hline
\end{tabular}


non-hydrogen atoms $[28,29]$. All $\mathrm{H}$ atoms were introduced in calculated positions with the isotropic displacement parameters fixed at 1.2 times the value of equivalent temperature factor of the parent carbon atoms. Crystal data collection and refinement parameters are given in Table 1 .

Computational details

All computations herein were performed by using GAUSSIAN-03 program package using hybrid DFTB3LYP functional [30]. The calculations were carried out using the standard $6-311+\mathrm{G}(\mathrm{d}, \mathrm{p})$ basis for $\mathrm{Cu}$ atom, $6-31+\mathrm{G}^{* *}$ basis for nitrogen, $6-31 \mathrm{G}^{*}$ for carbon, and 6-31G for hydrogen atoms. The geometry of $[\mathrm{Cu}(\mathrm{tppz})$ $(\mathrm{SCN})_{2}$ ] was optimized without any symmetry restrictions in the doublet state in gas phase and using PCM (polarizable continuum model) approach. The optimized geometry of $\left[\mathrm{Cu}(\mathrm{tppz})(\mathrm{SCN})_{2}\right]$ was verified by performing a frequency calculation. The vibrations in the calculated vibrational spectrum were real, thus the optimized geometry of $\left[\mathrm{Cu}(\mathrm{tppz})(\mathrm{SCN})_{2}\right]$ corresponds to true energy minimum.

The electronic spectrum of $\left[\mathrm{Cu}(\mathrm{tppz})(\mathrm{SCN})_{2}\right]$ was calculated with the TDDFT method starting from the experimental X-ray data. The solvent (methanol) effect was simulated using the polarizable continuum model with the integral equation formalism (IEF-PCM) [31, 32].

\section{Results and discussion}

The $\left[\mathrm{Cu}(\mathrm{tppz})(\mathrm{SCN})_{2}\right]$ complex has been obtained in the reaction of the copper(II) chloride with 2,3,5,6-tetra(2-pyridyl)pyrazine (tppz) and ammonium thiocyanate.
The IR spectrum of $\left[\mathrm{Cu}(\mathrm{tppz})(\mathrm{SCN})_{2}\right]$ clearly shows the presence of the thiocyanato groups. The maxima of $v_{\mathrm{CN}}$ strong absorptions occur at 2069 and $2046 \mathrm{~cm}^{-1}$, and their location is in good agreement with the end-on NCS coordination. The characteristic bands of the $\mathrm{C}=\mathrm{C}$ and $\mathrm{C}=\mathrm{N}$ stretching modes of 2,3,5,6-tetra-(2-pyridyl)pyrazine are observed in the range $1650-1520 \mathrm{~cm}^{-1}$ [33].

The calculated (non-scaled) vibrational spectrum of $\left[\mathrm{Cu}(\mathrm{tppz})(\mathrm{SCN})_{2}\right]$ stays in good agreement with experimental data, as shown in Fig. 1. The calculated $v_{\mathrm{CN}}$ strong absorptions occur at 2119.4 and $2099.7 \mathrm{~cm}^{-1}$. These values are higher than the experimental ones by $\sim 3 \%$, which is a usual feature for this approach. Similarly, the calculated absorptions due to $v(\mathrm{C}=\mathrm{N}), v(\mathrm{C}=\mathrm{C})$ modes of the tpp $z$, appearing at $1650-1510 \mathrm{~cm}^{-1}$, fall in the experimental range.

\section{Crystal structure}

The crystallographic data of $\left[\mathrm{Cu}(\mathrm{tppz})(\mathrm{SCN})_{2}\right]$ are summarized in Table 1 . The complex crystallises in the

Table 2 Short intra- and intermolecular contacts detected in structures $\left[\mathrm{Cu}(\mathrm{tppz})(\mathrm{SCN})_{2}\right]$

\begin{tabular}{lllll}
\hline $\mathrm{D}-\mathrm{H} \cdots \mathrm{A}$ & $\mathrm{D}-\mathrm{H}$ & $\mathrm{H} \cdots \mathrm{A}$ & $\mathrm{D} \cdots \mathrm{A}(\AA)$ & $\mathrm{D}-\mathrm{H} \cdots \mathrm{A}\left({ }^{\circ}\right)$ \\
\hline $\mathrm{C}(6)-\mathrm{H}(6) \cdots \mathrm{N}(6)$ & 0.93 & 2.48 & $2.984(4)$ & 114.0 \\
$\mathrm{C}(7)-\mathrm{H}(7) \cdots \mathrm{N}(98) \_\# 1$ & 0.93 & 2.61 & $3.431(5)$ & 148.0 \\
$\mathrm{C}(11)-\mathrm{H}(11) \cdots \mathrm{N}(5)$ & 0.93 & 2.54 & $2.990(4)$ & 110.0 \\
$\mathrm{C}(12)-\mathrm{H}(12) \cdots \mathrm{S}(98) \_\# 2$ & 0.93 & 2.84 & $3.508(4)$ & 129.0 \\
$\mathrm{C}(17)-\mathrm{H}(17) \cdots \mathrm{N}(98) \_\# 3$ & 0.93 & 2.61 & $3.510(5)$ & 163.0 \\
\hline
\end{tabular}

$\# 1:-1 / 2+x,-1 / 2-y, z ; \# 2: 1 / 2+x,-1 / 2-y,-1+z ; \# 3:$ $-1 / 2-\mathrm{x}, 1 / 2+y,-1 / 2+z$
Fig. 1 The experimental and calculated (non-scaled) vibrational spectra of $\left[\mathrm{Cu}(\mathrm{tppz})(\mathrm{SCN})_{2}\right]$

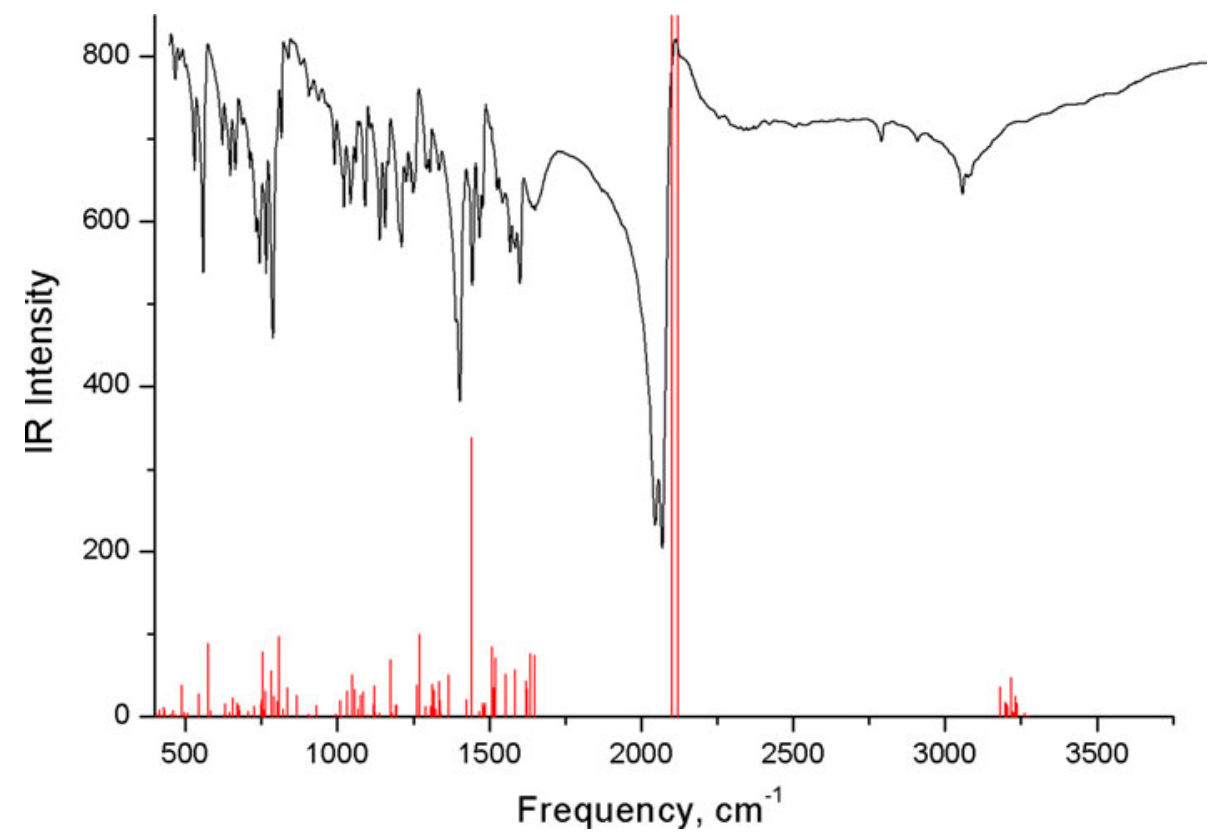




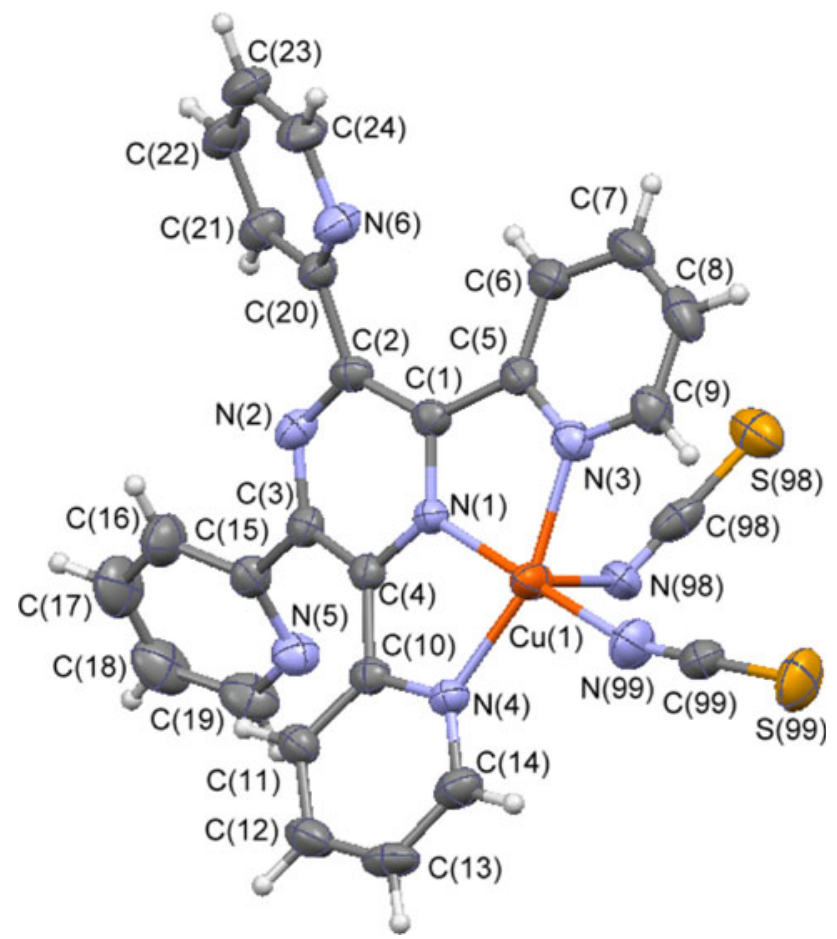

Fig. 2 The molecular structure of $\left[\mathrm{Cu}(\operatorname{tppz})(\mathrm{SCN})_{2}\right]$. Displacement ellipsoids are drawn at $50 \%$ probability

orthorhombic space group $\mathrm{Pna}_{1}$ and its structure consists of discrete and well-separated monomers $[\mathrm{Cu}(\mathrm{tppz})$ $\left.(\mathrm{SCN})_{2}\right]$. The intra- and intermolecular contacts [20, 22] detected in the structure are collected in Table 2. The structure is stabilized by some $\mathrm{C}-\mathrm{H} \cdots \mathrm{N}$ and $\mathrm{C}-\mathrm{H} \cdots \mathrm{S}$ short contacts classified as weak hydrogen bonds. The classical hydrogen bonds cannot be found [34, 35].

The molecular structure of $\left[\mathrm{Cu}(\mathrm{tppz})(\mathrm{SCN})_{2}\right]$ is presented in Fig. 2, and the selected bond distances and angles are collected in Table 3.

The copper(II) is five-coordinate by three $\mathrm{N}$ atoms of tppz ligand and two atoms of thiocyanate ions. The metal coordination geometry can be described as a distorted square pyramid.

The copper(II) ion displays a distorted square pyramidal environment $(4+1$ coordination). Three tppz nitrogen atoms $[\mathrm{Cu}(1)-\mathrm{N}(1)$ 1.946(2), $\mathrm{Cu}(1)-\mathrm{N}(3)$ 2.011(3), and $\mathrm{Cu}(1)-\mathrm{N}(1) 2.014(3) \AA]$ and one nitrogen atom of the thiocyanate group $[\mathrm{Cu}(1)-\mathrm{N}(99) 1.907(3) \AA]$ constitute the equatorial plane, and $\mathrm{N}(98)$ atom of the second $\mathrm{SCN}^{-}$ion is in apical position $[\mathrm{Cu}(1)-\mathrm{N}(98)$ distance $2.692(3) \AA]$. The angular structural index parameter $\tau$ [36] expressed here as the difference between the bond angles N(99)$\mathrm{Cu}(1)-\mathrm{N}(1)$ and $\mathrm{N}(3)-\mathrm{Cu}(1)-\mathrm{N}(4)$ divided by 60 has a value of 0.32 . The $\mathrm{Cu}(1)-\mathrm{N}(98)$ bond length is ca. $0.68 \AA$ longer than the $\mathrm{Cu}-\mathrm{N}$ distances in the equatorial plane, which makes $\left[\mathrm{Cu}(\mathrm{tppz})(\mathrm{SCN})_{2}\right]$ a very rare example of copper(II) complexes of general formula $[\mathrm{Cu}(\mathrm{N}-\mathrm{N}-$ $\mathrm{N})(\mathrm{NSC})_{2}$, where $\mathrm{N}-\mathrm{N}-\mathrm{N}$ stands a neutral tridentate $\mathrm{N}$-donor ligand. Generally, the elongation of the apical $\mathrm{Cu}-\mathrm{N}$ bond in $\left[\mathrm{Cu}(\mathrm{N}-\mathrm{N}-\mathrm{N})(\mathrm{NSC})_{2}\right]$ compounds is much smaller and falls in the range 0.08-0.37 ̊ [37]. Such long distance to thiocyanate group in apical position indicates very weak $\mathrm{Cu}(1)-\mathrm{N}(98)$ coordination bond. The thiocyanate groups are quasi-linear with values of the $\mathrm{N}-\mathrm{C}-\mathrm{S}$ angle of $178.8(4)^{\circ}$ and $179.3(4)^{\circ}$.

Table 3 The experimental and optimized bond lengths $(\AA)$ and angles $\left(^{\circ}\right)$ for $\left[\mathrm{Cu}(\operatorname{tppz})(\mathrm{SCN})_{2}\right]$

\begin{tabular}{|c|c|c|c|c|c|c|c|}
\hline \multicolumn{4}{|l|}{ Bond lengths } & \multicolumn{4}{|l|}{ Bond angles } \\
\hline & \multirow[t]{2}{*}{ Experimental } & \multicolumn{2}{|l|}{ Optimized } & & \multirow[t]{2}{*}{ Experimental } & \multicolumn{2}{|l|}{ Optimized } \\
\hline & & Gas phase & PCM method & & & Gas phase & PCM method \\
\hline $\mathrm{Cu}(1)-\mathrm{N}(1)$ & $1.946(2)$ & 2.015 & 1.993 & $\mathrm{~N}(1)-\mathrm{Cu}(1)-\mathrm{N}(3)$ & 79.78(10) & 78.52 & 78.73 \\
\hline $\mathrm{Cu}(1)-\mathrm{N}(3)$ & $2.011(3)$ & 2.069 & 2.064 & $\mathrm{~N}(1)-\mathrm{Cu}(1)-\mathrm{N}(4)$ & $80.20(10)$ & 77.93 & 79.05 \\
\hline $\mathrm{Cu}(1)-\mathrm{N}(4)$ & $2.014(3)$ & 2.077 & 2.057 & $\mathrm{~N}(3)-\mathrm{Cu}(1)-\mathrm{N}(4)$ & $159.69(11)$ & 153.75 & 156.00 \\
\hline $\mathrm{Cu}(1)-\mathrm{N}(99)$ & $1.907(3)$ & 1.925 & 1.946 & $\mathrm{~N}(99)-\mathrm{Cu}(1)-\mathrm{N}(1)$ & $178.57(18)$ & 158.76 & 159.60 \\
\hline $\mathrm{Cu}(1)-\mathrm{N}(98)$ & $2.692(3)$ & 2.166 & 2.215 & $\mathrm{~N}(99)-\mathrm{Cu}(1)-\mathrm{N}(3)$ & $99.88(12)$ & 101.23 & 98.18 \\
\hline $\mathrm{S}(98)-\mathrm{C}(98)$ & $1.630(4)$ & 1.638 & 1.649 & $\mathrm{~N}(99)-\mathrm{Cu}(1)-\mathrm{N}(4)$ & $100.21(12)$ & 96.55 & 99.48 \\
\hline N(98)-C(98) & $1.139(5)$ & 1.188 & 1.185 & $\mathrm{~N}(98)-\mathrm{Cu}(1)-\mathrm{N}(1)$ & $80.30(12)$ & 88.62 & 97.60 \\
\hline S(99)-C(99) & $1.612(3)$ & 1.620 & 1.697 & $\mathrm{~N}(98)-\mathrm{Cu}(1)-\mathrm{N}(3)$ & $88.36(11)$ & 91.79 & 93.52 \\
\hline \multirow[t]{5}{*}{$\mathrm{N}(99)-\mathrm{C}(99)$} & $1.163(4)$ & 1.190 & 1.181 & $\mathrm{~N}(98)-\mathrm{Cu}(1)-\mathrm{N}(4)$ & $91.66(10)$ & 99.07 & 98.30 \\
\hline & & & & $\mathrm{C}(99)-\mathrm{N}(99)-\mathrm{Cu}(1)$ & $163.1(3)$ & 152.60 & 179.93 \\
\hline & & & & $\mathrm{C}(98)-\mathrm{N}(98)-\mathrm{Cu}(1)$ & $115.3(3)$ & 126.68 & 144.66 \\
\hline & & & & $\mathrm{N}(98)-\mathrm{C}(98)-\mathrm{S}(98)$ & $178.8(4)$ & 177.00 & 178.79 \\
\hline & & & & $\mathrm{N}(99)-\mathrm{C}(99)-\mathrm{S}(99)$ & 179.3(4) & 178.86 & 179.96 \\
\hline
\end{tabular}


The tppz ligand is appreciably twisted, dihedral angles between the pyrazine ring and each of the pyridyl rings are equal $14.99(11)^{\circ}, 19.47(11)^{\circ}, 30.16(7)^{\circ}$, and $34.97(8)^{\circ}$. The first two values concern coordinated pyridyl rings. The pyrazine ring itself is puckered with maximum atomic deviations from a best mean plane being $0.0907 \AA$ at $\mathrm{C}(4)$. The torsion angles N1-C1-C2-N2 and N2-C3-C4-N1 are $-16.3(8)$ and $-16.8(4)^{\circ}$, respectively, and the dihedral angle between the two $\mathrm{C}-\mathrm{N}-\mathrm{C}$ planes of the pyrazine ring is $8.79(10)^{\circ}$. The value of the dihedral angle between the mean plane of the pyrazine ring and the equatorial plane defined by $\mathrm{Cu}(1), \mathrm{N} 1(1), \mathrm{N}(3), \mathrm{N}(4)$, and $\mathrm{N}(99)$ is practically identical and equals $9.57(8)^{\circ}$. The non-planarity of the pyrazine ring is unexceptional. It has been reported for the related structures [20, 23-25], and the factor responsible for destabilizing the planar geometry of the pyrazine ring has a pure electronic origin [38].

\section{Geometry optimization}

The geometry of $\left[\mathrm{Cu}(\mathrm{tppz})(\mathrm{SCN})_{2}\right]$ was optimized in doublet state using the DFT method with the B3LYP functional in gas phase and using PCM (polarizable continuum model) approach. The calculated geometric parameters are gathered in Table 3. The optimized geometry of $\left[\mathrm{Cu}(\mathrm{tppz})(\mathrm{SCN})_{2}\right]$ displays a distorted square pyramidal environment, and general trends observed in the experimental data are satisfactorily reproduced in the

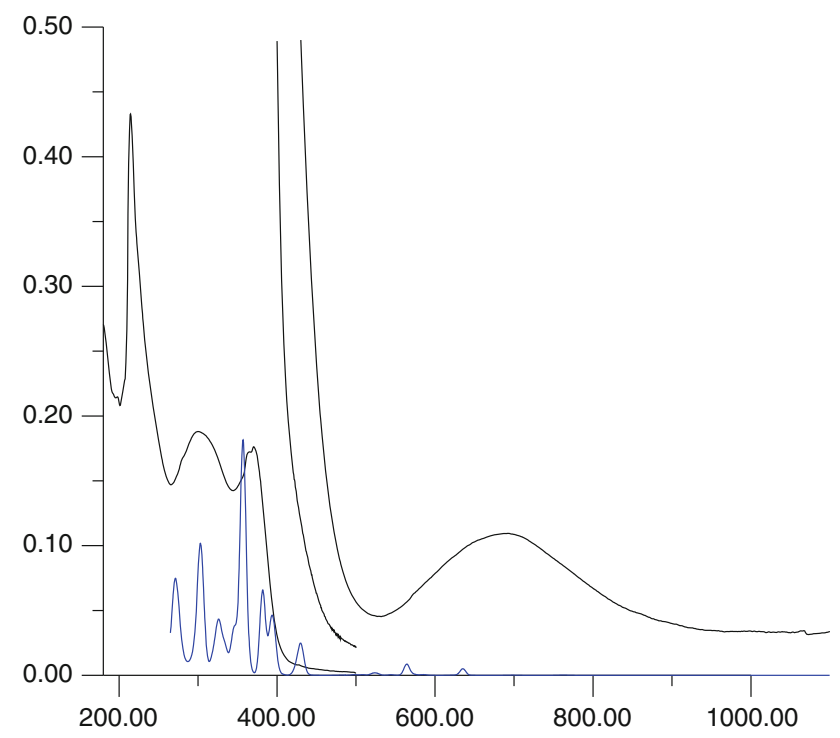

Fig. 3 The experimental (black) and calculated (blue) electronic absorption spectra of $\left[\mathrm{Cu}(\mathrm{tppz})(\mathrm{SCN})_{2}\right]($ Color figure online)

calculations. However, the calculated $\mathrm{Cu}-\mathrm{N}_{\text {apical }}$ distance is significantly lower in comparison with the experimental value, both for gas phase and PCM optimization. Due to the discrepancy between experimental and calculated values of the apical $\mathrm{Cu}-\mathrm{N}$ bond in $\left[\mathrm{Cu}(\mathrm{tppz})(\mathrm{SCN})_{2}\right]$, TDDFT calculations were performed starting from the experimental data.

Table 4 The spin-allowed doublet-doublet electronic transitions calculated with the TDDFT method and the assignments of the calculated transitions to the experimental absorption bands of $\left[\mathrm{Cu}(\mathrm{tppz})(\mathrm{SCN})_{2}\right]$

\begin{tabular}{|c|c|c|c|c|c|c|c|}
\hline \multirow[t]{2}{*}{ The most important orbital excitations } & \multirow[t]{2}{*}{ Character } & \multirow[t]{2}{*}{$\lambda(\mathrm{nm})$} & \multirow[t]{2}{*}{$E(\mathrm{eV})$} & \multirow[t]{2}{*}{$f$} & \multicolumn{3}{|c|}{ Experimental } \\
\hline & & & & & $\Lambda(\mathrm{nm})$ & $E(\mathrm{eV})$ & $\varepsilon$ \\
\hline $\mathrm{H}(\beta) \rightarrow \mathrm{L}(\beta)$ & $\pi(\mathrm{SCN}) \rightarrow \mathrm{d} / \pi^{*}(\mathrm{tppz})$ & 698.28 & 1.78 & 0.0002 & 693.5 & 1.79 & 125 \\
\hline $\mathrm{H}-3(\beta) \rightarrow \mathrm{L}(\beta)$ & $\pi(\mathrm{SCN}) / \mathrm{d} \rightarrow \mathrm{d} / \pi^{*}(\mathrm{tppz})$ & 635.22 & 1.95 & 0.0101 & & & \\
\hline $\mathrm{H}(\beta) \rightarrow \mathrm{L}+1(\beta)$ & $\pi(\mathrm{SCN}) \rightarrow \pi^{*}(\mathrm{tppz}) / \mathrm{d}$ & 572.43 & 2.17 & 0.0015 & & & \\
\hline $\mathrm{H}-1(\alpha) \rightarrow \mathrm{L}(\alpha) \mathrm{H}-1(\beta) \rightarrow \mathrm{L}+1(\beta)$ & $\begin{aligned} \pi(\mathrm{SCN}) / \mathrm{d} & \rightarrow \pi^{*}(\mathrm{tppz}) / \mathrm{d} \\
\pi(\mathrm{SCN}) / \mathrm{d} & \rightarrow \pi^{*}(\mathrm{tppz}) / \mathrm{d}\end{aligned}$ & 564.23 & 2.20 & 0.0171 & & & \\
\hline $\mathrm{H}-4(\beta) \rightarrow \mathrm{L}(\beta)$ & $\pi(\operatorname{tppz}) \rightarrow \mathrm{d} / \pi^{*}(\mathrm{tppz})$ & 430.44 & 2.88 & 0.0143 & 372.0 & 3.33 & 1225 \\
\hline $\mathrm{H}-2(\beta) \rightarrow \mathrm{L}+1(\beta)$ & $\pi(\mathrm{SCN}) / \mathrm{d} \rightarrow \pi^{*}(\mathrm{tppz}) / \mathrm{d}$ & 429.23 & 2.89 & 0.0299 & & & \\
\hline $\mathrm{H}-2(\beta) \rightarrow \mathrm{L}+2(\beta)$ & $\pi(\mathrm{SCN}) / \mathrm{d} \rightarrow \pi^{*}(\mathrm{tppz}) / \mathrm{d}$ & 396.39 & 3.13 & 0.0449 & & & \\
\hline $\mathrm{H}-2(\beta) \rightarrow \mathrm{L}+2(\beta)$ & $\pi(\mathrm{SCN}) / \mathrm{d} \rightarrow \pi^{*}(\mathrm{tppz}) / \mathrm{d}$ & 392.38 & 3.16 & 0.0586 & & & \\
\hline $\mathrm{H}-5(\alpha) \rightarrow \mathrm{L}(\alpha)$ & $\pi(\mathrm{tppz}) / \mathrm{d} \rightarrow \pi^{*}(\mathrm{tppz}) / \mathrm{d}$ & 381.71 & 3.24 & 0.1307 & & & \\
\hline $\mathrm{H}-7(\beta) \rightarrow \mathrm{L}(\beta)$ & $\pi(\mathrm{tppz}) \rightarrow \mathrm{d} / \pi^{*}(\mathrm{tppz})$ & 359.32 & 3.45 & 0.0666 & 300.5 & 4.13 & 5000 \\
\hline $\mathrm{H}-4(\beta) \rightarrow \mathrm{L}+2(\beta)$ & $\pi(\mathrm{tppz}) \rightarrow \pi^{*}(\mathrm{tppz}) / \mathrm{d}$ & 356.43 & 3.48 & 0.3096 & & & \\
\hline $\mathrm{H}-7(\alpha) \rightarrow \mathrm{L}(\alpha)$ & $\pi(\mathrm{tppz}) \rightarrow \pi^{*}(\mathrm{tppz}) / \mathrm{d}$ & 325.14 & 3.81 & 0.0373 & & & \\
\hline $\mathrm{H}-6(\alpha) \rightarrow \mathrm{L}+1(\alpha)$ & $\pi(\operatorname{tppz}) \rightarrow \pi^{*}(\operatorname{tppz})$ & 305.86 & 4.05 & 0.0749 & & & \\
\hline $\mathrm{H}-5(\beta) \rightarrow \mathrm{L}+2(\beta)$ & $\pi(\mathrm{tppz}) \rightarrow \pi^{*}(\mathrm{tppz}) / \mathrm{d}$ & 301.66 & 4.11 & 0.1227 & & & \\
\hline $\mathrm{H}-5(\beta) \rightarrow \mathrm{L}+2(\beta)$ & $\pi(\operatorname{tppz}) \rightarrow \pi^{*}(\mathrm{tppz}) / \mathrm{d}$ & 270.64 & 4.58 & 0.0929 & & & \\
\hline
\end{tabular}

$\varepsilon$ molar absorption coefficient $\left[\mathrm{dm}^{3} \mathrm{~mol}^{-1} \mathrm{~cm}^{-1}\right], f$ oscillator strength, $H$ highest occupied molecular orbital, $L$ lowest unoccupied molecular orbital 
Fig. 4 The energy (eV), character, and some contours of the unoccupied molecular orbitals of $\left[\mathrm{Cu}(\mathrm{tppz})(\mathrm{SCN})_{2}\right]$. Positive values of the orbital contour are represented in blue and negative values in gray

(Color figure online)

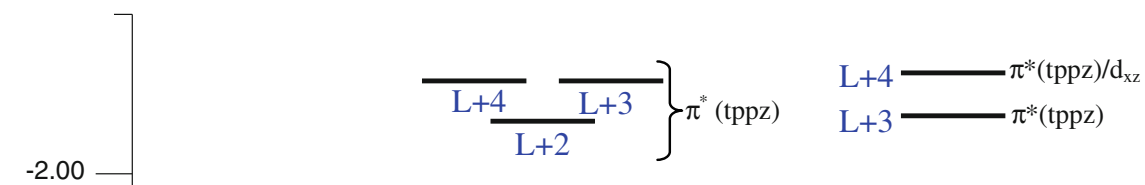

$\mathrm{L}+2 \longrightarrow \pi^{*}(\mathrm{tppz}) / \mathrm{d}_{\mathrm{x}-\mathrm{y}}^{2}{ }^{2}$

$\mathrm{L}+1=\pi^{*}(\mathrm{tppz})$

$\mathrm{L}+1 \longrightarrow \pi^{*}(\mathrm{tppz}) / \mathrm{d}_{\mathrm{yz}}$

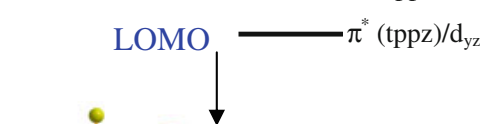

LOMO $-\mathrm{d}_{\mathrm{x}-\mathrm{y}}^{2} / \pi^{2}(\mathrm{tppz})$
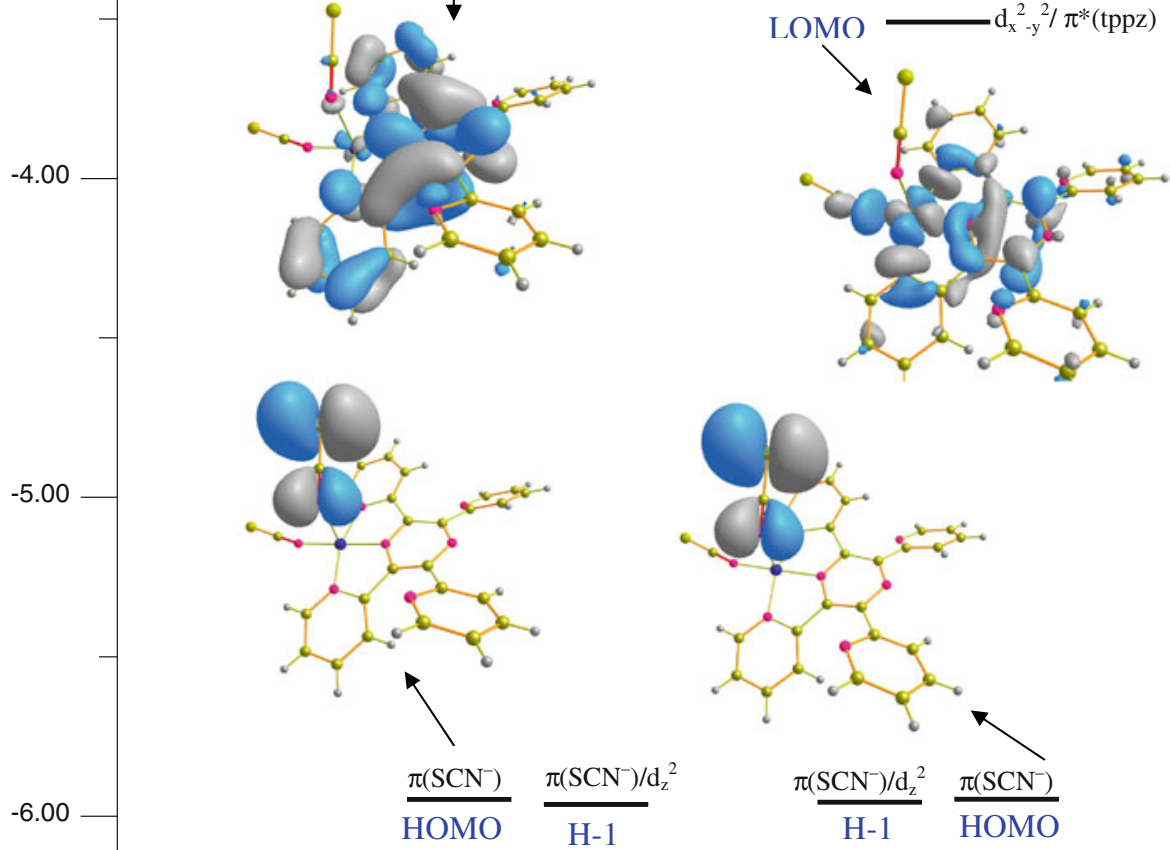

$-5.00$

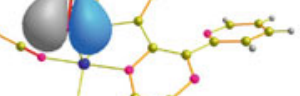

$-$

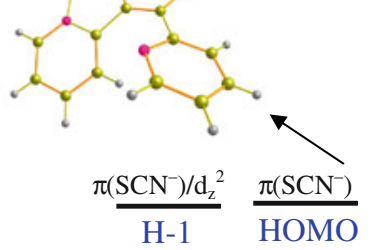

$\frac{\pi\left(\mathrm{SCN}^{-}\right) / \mathrm{d}_{\mathrm{yz}}}{\mathrm{H}-2} \frac{\pi\left(\mathrm{SCN}^{-}\right) / \mathrm{d}_{\mathrm{xy}}}{\mathrm{H}-3}$

$\frac{\pi\left(\mathrm{SCN}^{-}\right) / \mathrm{d}_{\mathrm{yz}}}{\mathrm{H}-2} \frac{\pi\left(\mathrm{SCN}^{-}\right) / \mathrm{d}_{\mathrm{xy}}}{\mathrm{H}-3}$

$\alpha$-spin
Electronic spectrum

The electronic absorption spectrum of $\left[\mathrm{Cu}(\mathrm{tppz})(\mathrm{SCN})_{2}\right]$ in methanol is given in Fig. 3. The complex $[\mathrm{Cu}(\mathrm{tppz})$ $(\mathrm{SCN})_{2}$ ] shows three well-resolved bands in the UV region: an intense and sharp peak centered at $213.5 \mathrm{~nm}$ and two less intense absorptions located at 300.5 and $372.0 \mathrm{~nm}$. The lowest-energy absorption band originates from LLCT transitions, whereas the bands in the range
$400-300 \mathrm{~nm}$ are generally attributed to the LMCT transitions.

In addition, the solution spectrum of $\left[\mathrm{Cu}(\mathrm{tppz})(\mathrm{SCN})_{2}\right]$ displays a single broad band with maximum at $693.5 \mathrm{~nm}$. This absorption is attributed to ligand-field transitions, and its location is consistent with the five-coordinate geometry with $\mathrm{Cu}$ (II) ion adapting a distorted SP geometry. $\mathrm{Cu}$ (II) complexes with TBP geometry usually show a maximum at $\lambda>800 \mathrm{~nm}$ with a higher energy shoulder [3]. 
For more qualitative description of the electronic absorption spectrum, the nature of electronic transitions was investigated by the time-dependent density functional (TDDFT) method. The TDDFT calculations of $[\mathrm{Cu}(\mathrm{tppz})$ $(\mathrm{SCN})_{2}$ ] were performed starting from the experimental data (Fig. 3). The investigated complex is of large size. The number of basis functions is equal 746 and 120 electron transitions calculated by the TDDFT method do not comprise all the experimental absorption bands. The shortest wavelength experimental band of $[\mathrm{Cu}(\mathrm{tppz})$ $(\mathrm{SCN})_{2}$ ] is not assigned to the calculated transitions. As the solution spectrum of 2,3,5,6-tetra-(2-pyridyl)pyrazine exhibits intense absorption in this region, some additional intraligand transitions $\pi(\mathrm{tppz}) \rightarrow \pi^{*}(\mathrm{tppz})$ are expected to be found at higher energies in the calculations for $\left[\mathrm{Cu}(\mathrm{tppz})(\mathrm{SCN})_{2}\right]$. In Fig. 3, each calculated transition is represented by a Gaussian function $y=c e^{-b x^{2}}$ with the height $(c)$ equal to the oscillator strength and $b$ equal to $0.04 \mathrm{~nm}^{-2}$. As can be seen from Fig. 3, the calculated curves are nicely fitted to those from the experimental measurements.

Table 4 presents the most important electronic transitions calculated with the TDDFT method, assigned to the observed absorption bands of $\left[\mathrm{Cu}(\mathrm{tppz})(\mathrm{SCN})_{2}\right]$. The assignment of the calculated orbital excitations to the experimental bands was based on an overview of the contour plots and relative energy to the occupied and unoccupied orbitals involved in the electronic transitions. The simplified molecular orbital diagram of $\left[\mathrm{Cu}(\mathrm{tppz})(\mathrm{SCN})_{2}\right]$ is presented in Fig. 4.

The TDDFT/PCM calculations show that the longest wavelength experimental with maximum at $693.5 \mathrm{~nm}$ involves the transitions between $\beta$-spin HOMO-3, HOMO1, HOMO and LUMO, LUMO +1 as well as the transition between $\alpha$-spin HOMO-1 and LUMO. The LUMO orbital with $\beta$ spin is mainly $d_{x^{2}-y^{2}}$ copper orbital in character, whereas the spin HOMO-3, HOMO-1, and HOMO are nonbonding combination of a sulfur lone pair and nitrogen $p$ orbital localized on the thiocyanate ligands with admixture of $\mathrm{d}_{\mathrm{Cu}}$ orbitals. $\beta$-spin LUMO +1 and $\alpha$-spin LUMO are of mixed character $\mathrm{d}_{\mathrm{Cu}}+\pi_{\text {tppz }}^{*}$. Accordingly, the transitions assigned to the absorption at $693.5 \mathrm{~nm}$ can be seen as mixed $\mathrm{d} \rightarrow \mathrm{d}(L F), \mathrm{SCN}^{-} \rightarrow \mathrm{d}(L M C T)$, and $\mathrm{SCN}^{-} \rightarrow$ tppz ( $L L C T)$, or a delocalized MLLCT (metal-ligand-toligand $\mathrm{CT}$ ) description can be used.

The absorption bands at 372.0 and $300.5 \mathrm{~nm}$ involve a multitude of electronic transitions calculated in the 400-270 nm region, but maximum contributions are from $\mathrm{H}-5(\alpha) \rightarrow \mathrm{L}(\alpha), \quad \mathrm{H}-4(\beta) \rightarrow \mathrm{L}+2(\beta), \quad \mathrm{H}-6(\alpha) \rightarrow \mathrm{L}+1(\alpha)$, and $\mathrm{H}-5(\beta) \rightarrow \mathrm{L}+2(\beta)$. These transitions can be seen as mixed tppz $\rightarrow \mathrm{Cu}$ (Ligand-Metal Charge Transfer; LMCT) and $\pi(\mathrm{tppz}) \rightarrow \pi^{*}(\mathrm{tppz})$ (intraligand charge transfer).

\section{Supplementary data}

Supplementary data for $\mathrm{C}_{26} \mathrm{H}_{16} \mathrm{CuN}_{8} \mathrm{~S}_{2}$ are available from the CCDC, 12 Union Road, Cambridge CB2 1EZ, UK on request, quoting the deposition number CCDC 866822.

Acknowledgments The Gaussian03 calculations were carried out in the Wrocław Centre for Networking and Supercomputing, WCSS, Wrocław, Poland under calculational Grant No. 18.

Open Access This article is distributed under the terms of the Creative Commons Attribution License which permits any use, distribution, and reproduction in any medium, provided the original author(s) and the source are credited.

\section{References}

1. Talukder P, Datta A, Mitra S, Rosair G, Fallah MSE, Ribas J (2004) Dalton Trans 4161

2. Youngme S, Phatchimkun J, Suksangpanya U, Pakawatchai $\mathrm{Ch}$, van Albada GA, Quesada M, Reedijk J (2006) Inorg Chem Commun 9:242

3. Mautner FA, Louka FR, LeGuet T, Massoud SS (2009) J Mol Struct 919:196

4. Kong L, Li W-J, Li X-L, Geng W-Q, Hao F-Y, Wua J-Y, Zhou H-P, Yang J-X, Tian Y-P, Jin B-K (2010) Polyhedron 29:1575

5. Carranza J, Sletten J, Lloret F, Julve M (2009) Polyhedron 28:2249

6. Ribas J, Escuer A, Monfort M, Vicente R, Cortes R, Lezama L, Rojo T (1999) Coord Chem Rev 193-195:1027

7. Ohba M, Okawa H (2000) Coord Chem Rev 198:313

8. Adhikarya C, Koner S (2010) Coord Chem Rev 254:2933

9. Escuer A, Vicente R, Goher MAS, Mautner FA (1997) J Chem Soc Dalton Trans 4431

10. Villanueva M, Mesa JL, Urtiaga MK, Cortés R, Lezama L, Arriortua MI, Rojo T (2001) Eur J Inorg Chem 1581

11. Cano J, Journaux Y, Goher MAS, Abu-Youssef MAM, Mautner FA, Rei $\beta$ GJ, Escuer A, Vicentee R (2005) New J Chem 29:306

12. Gao E-Q, Wang Z-M, Yan C-H (2003) Chem Commun 1748

13. Han S, Manson JL, Kim J, Miller JS (2000) Inorg Chem 39:4182

14. Martin S, Barandika MG, Lezama L, Pizarro JL, Serna ZE, de Larramendi JIR, Arriortua MI, Rojo T, Cortés R (2001) Inorg Chem 40:4109

15. Fu AH, Huang XY, Li J, Yuen T, Lin CL (2002) Chem Eur J $8: 2239$

16. Goodwin HA, Lions F (1959) J Am Chem Soc 81:6415

17. Chanda N, Laye RH, Chakraborty S, Paul RL, Jeffery JC, Ward MD, Lahiri GK (2002) J Chem Soc Dalton Trans 3496

18. Toma LM, Armentano D, De Munno G, Sletten J, Lloret F, Julve M (2007) Polyhedron 26:5263

19. Heirtzler F, Santi S, Howland K, Weyhermüller T (2006) Dalton Trans 4722

20. Carranza J, Sletten J, Brennan C, Lloret F, Cano J, Julve M (2004) Dalton Trans 3997

21. Graf M, Greaves B, Stoeckli-Evans H (1993) Inorg Chim Acta 204:239

22. Graf M, Stoeckli-Evans H, Escuer A, Vicente R (1997) Inorg Chim Acta 257:89

23. Hadadzadeh H, Rezvani AR, Yap GPA, Crutchley RJ (2005) Inorg Chim Acta 358:1289-1292 
24. Carranza J, Brennan C, Sletten J, Clemente-Juan JM, Lloret F, Julve M (2003) Inorg Chem 42:8716

25. Yuste C, Armentano D, Marino N, Cañadillas-Delgado L, Delgado FS, Ruiz-Pérez C, Rillema DP, Lloret F, Julve M (2008) Dalton Trans 1583

26. Koch W, Holthausen MC (2000) A chemist's guide to density functional theory. Wiley-VCH, Weinheim

27. Oxford Diffraction (2011) CrysAlis PRO. Oxford Diffraction Ltd, Yarnton

28. Sheldrick GM (1997) SHELXS-97. Program for crystal structure resolution. University of Göttingen, Göttingen

29. Sheldrick GM (1997) SHELXL-97. Program for crystal structures analysis. University of Göttingen, Göttingen

30. Frisch MJ, Trucks GW, Schlegel HB, Scuseria GE, Robb MA, Cheeseman JR, Scalmani G, Barone V, Mennucci B, Petersson GA, Nakatsuji H, Caricato M, Li X, Hratchian HP, Izmaylov AF, Bloino J, Zheng G, Sonnenberg JL, Hada M, Ehara M, Toyota K, Fukuda R, Hasegawa J, Ishida M, Nakajima T, Honda Y, Kitao O, Nakai H, Vreven T, Montgomery JA, Jr., Peralta JE, Ogliaro F, Bearpark M, Heyd JJ, Brothers E, Kudin KN, Staroverov VN, Kobayashi R, Normand J, Raghavachari K, Rendell A, Burant JC, Iyengar SS, Tomasi J, Cossi M, Rega N, Millam JM, Klene M, Knox JE, Cross JB, Bakken V, Adamo C, Jaramillo J, Gomperts
R, Stratmann RE, Yazyev O, Austin AJ, Cammi R, Pomelli C, Ochterski JW, Martin RL, Morokuma K, Zakrzewski VG, Voth GA, Salvador P, Dannenberg JJ, Dapprich S, Daniels AD, Farkas O, Foresman JB, Ortiz JV, Cioslowski J, Fox DJ (2009) Gaussian 09, Revision A.1. Gaussian, Inc., Wallingford CT

31. Casida ME (1996) In: Seminario JM (ed) Recent developments and applications in modern density functional theory, theoretical and computational chemistry, vol 4. Elsevier, Amsterdam

32. Cossi M, Scalmani G, Rega N, Barone V (2002) J Chem Phys 117:43

33. Nakamoto K (1986) Infrared and Raman spectra of inorganic and coordination compounds, 4th edn. Wiley-Interscience, New York

34. Desiraju GR, Steiner T (1999) The weak hydrogen bond in structural chemistry and biology. Oxford University Press, Oxford

35. Jeffrey GA, Saenger W (1994) Hydrogen bonding in biological structures. Springer, Berlin

36. Addison AW, Rao TN, Reedijk J, Rijn J, Verschoor GC (1984) J Chem Soc Dalton Trans 1349

37. Allen FH (2002) Acta Cryst B58:380

38. Shishkin OV, Pichugin KY, Gorb L, Leszczyński J (2002) J Mol Struct 616:159 